\section{AL-AZHAR}

Assiut Dental Journal
The Official Publication of The

Faculty of Dental medicine.

Al-Azhar Assiut Uniuersity.

AADJ, Vol. 3, No. 2, October (2020) - PP. 129:137

ISSn 2682-2822

\title{
Effect of Incorporation of Henna and Silver-nanoparticles on Surface Properties of PMMA Acrylic Resin
}

\author{
Gamal Mokhtar Alwafy ${ }^{* 1}$, Mostafa Ibrahim Fayad ${ }^{* 1,2}$, Ramy Abdallah Abdelrahim ${ }^{3}$, Osama Abuhelal ${ }^{1}$
}

Codex : 16/2020/10

Aadj@azhar.edu.eg

\section{KEYWORDS}

Heat-cured PMMA, Henna,

Silver-nanoparticles,

Surface properties,

Surface hardness.

1. Department of Removable Prosthodontics, Faculty of Dental Medicine (Boys) Cairo ,Al-Azhar University, Egypt.

2. Department of Substitutive Dental Science, College of Dentistry, Taibah University, kingdom of Saudi Arabia.

3. Department of Dental Biomaterials, Faculty of Dental Medicine (Boys) Cairo ,Al-Azhar University, Egypt.

* Corresponding Author e-mail: dr.mifayad@azhar.edu.eg

\begin{abstract}
Aim: This study was aimed to evaluate the effect of Henna fillers and silvernanoparticles (Ag-Nps) fillers on surface properties of PMMA acrylic resin. Subjects and methods: One type of conventional heat-cured acrylic resin (Vertex tm Rapid simplified), Henna with a concentration of $1 \%$ by weight (Egyptian Local industry), and silver nanoparticles (Ag-Nps) with a concentration of $0.5 \%$ by weight (Nano-gate Company Egypt); were selected for this study. The different fillers were added to the polymer powder and was stirred with an electric mixer before mixing with monomer, mixing, packing, and processing was done using the conventional water bath method. After processing, all specimens were finished and polished, then kept in distilled water till tested. All modified and unmodified (control) specimens were used to measure surface hardness and surface roughness. Statistical data analysis was conducted via SPSS program . Results: Incorporation of Henna and Ag-Nps significantly decrease surface hardness of PMMA acrylic resin. While they insignificantly decrease its surface roughness. Conclusion: Surface hardness of PMMA acrylic resin adversely affected by the incorporation of fillers, while surface roughness improved.
\end{abstract}

\section{INTRODUCTION}

PMMA acrylic resin is the most commonly used material for the fabrication of complete and partial denture bases which may be attributed to its ease of fabrication, easy repair, low cost, lightweight, and color matching ability ${ }^{(1-4)}$. However, this material is not fulfilling the all ideal requirements of denture base material and has many shortcomings which can cause prosthesis failure ${ }^{(5,6)}$.

PMMA dentures have many mechanical and physical drawbacks such as low flexural strength ${ }^{(7)}$, weak impact strength ${ }^{(8)}$, low hardness, surface porosity ${ }^{(9)}$, residual monomers, dimensional instability, water sorption, and solubility ${ }^{(10)}$. 
To overcome these drawbacks, several researchers have been reported about the improvement of mechanical and physical properties PMMA denture base polymers by incorporation of different reinforcing materials such as metal fillers, glass and polymeric fibers, and nanoparticles such as Ag-Nps ${ }^{(1,3,11,12)}$.

It was found that the size, shape, and distribution of filler particles in the polymer matrix, strong adhesion at the matrix/filler interface and degree of polymerization play a significant role in the mechanical properties of filled polymer composites ${ }^{(3,13)}$. The lower degree of polymerization conversion is usually associated with greater number of residual unreacted monomers which can act as a plasticizer and reduces the mechanical properties of the resulted polymer ${ }^{(3,14,15)}$.

Recently, various researches attempted to study the influence of incorporation of natural powder fillers such as Lawsonia inermis (Henna), pomegranate peels, seed powder of dates Ajwa, and neem on biological, physical, and mechanical properties of PMMA acrylic resin ${ }^{(16-19)}$.

Numerous studies have been reported about the incorporation of Ag-Nps and Henna powder into conventional heat-cured PMMA acrylic resin that may act as good antimicrobial agents ${ }^{(20,21)}$. However, the effect of incorporation of $\mathrm{Ag}-\mathrm{Nps}$ and Henna powder as reinforcement fillers has not been substantiated and very limited literature is available on the effect of these materials on the physical and mechanical properties of PMMA acrylic resins. ${ }^{(3,19)}$.

The previous studies found that the minimum antimicrobial inhibitory concentration of $\mathrm{Ag}-\mathrm{Nps}$ and Henna fillers which incorporated in acrylic resins without significant adverse effect on their mechanical properties was $1 \mathrm{wt} . \%, 0.5 \mathrm{wt} . \%$ for Henna and Ag-Nps respectively ${ }^{(18,19,22-24)}$. So, in this study, we choose these minimum inhibitory concentrations as a base-line in evaluating their effect on surface hardness and surface roughness of heat-cured PMMA acrylic resin.
This study was essentially designed to evaluate and compare the influence of the addition of Ag-Nps and Henna fillers on surface properties of PMMA heat-cured acrylic resin.

\section{MATERIALS AND METHODS}

A power analysis of sample size revealed that a total of 132 specimens $(n=11)$ was required. This study involved an in-vitro investigation of 132 specimens of heat-cured acrylic resin were prepared according to; American Dental Association (ADA) specification specimens' dimensions for each test, $(65 \times 10 \times 2.5 \mathrm{~mm})$ for flexural strength ${ }^{(25)}$, $(20 \times 3 \mathrm{~mm})$ for hardness and surface roughness ${ }^{(26)}$, and $(20 \times 1 \mathrm{~mm})$ for water sorption and solubility test $^{(27)}$.

\section{Sample Grouping:}

This study has been divided into three main groups according to additives incorporated in PMMA;

Group 1: A total number of 44 specimens of conventional PMMA heat-cured acrylic resin (unmodified) as (Control Group) $(\mathrm{n}=44)$.

Group 2: A total number of 44 specimens PMMA containing 1wt. \% Henna particles that incorporated into PMMA acrylic resin $(n=44)$.

Group 3: A total number of 44 specimens PMMA containing concentrations of $0.5 \mathrm{wt} . \% \mathrm{Ag}$ NPs that incorporated into PMMA acrylic resin $(n=44)$.

Each main group was subdivided into four subgroups according to the type of test $(n=11)$ (flexural strength, micro-hardness, surface roughness, and water sorption and solubility).

\section{Specimens Fabrication:}

A stainless-steel mold with internal dimensions of $(65 \times 10 \times 2.5 \mathrm{~mm})$ for flexural strength test, $(20 \times 3 \mathrm{~mm})$ for micro-hardness and surface 
roughness tests, and $(20 \times 1 \mathrm{~mm})$ for water sorption and solubility test were used to fabricate 132 wax specimens, thirty-three specimens for each test $(n=33)$. Modified polymers powders are prepared by addition Henna and Ag-Nps fillers to the powder of PMMA resin with a proportion of 1 and $0.5 \mathrm{wt} . \%$ respectively using a digital balance (Precisa 205A; Moosmattstrasse, Dietikon, Switzerland), and was stirred with an electric mixer before mixing with monomer.

According to type of test; each stainless-steel metal plates painted with a separating medium, and then flasked with plaster into a metal flask, after complete setting of plaster, the top half of the metal flask and the stainless-steel metal plates removed leaving spaces in plaster of the bottom half of flask with the same dimension of each stainless-steel metal plates. Then, the mold painted with a separating medium for the application of PMMA acrylic resin of different main groups (Figure 1). Then, the unmodified and modified acrylic resin powders were mixed with monomer liquid according to the manufacturer's instructions (1:1 by volume). The specimens then were packed into the specially designed stone mold in the dough stage and flasked. Then, the specimens were polymerized through immersion in a temperature-controlled curing water bath for 6 hours ${ }^{(28,29)}$.

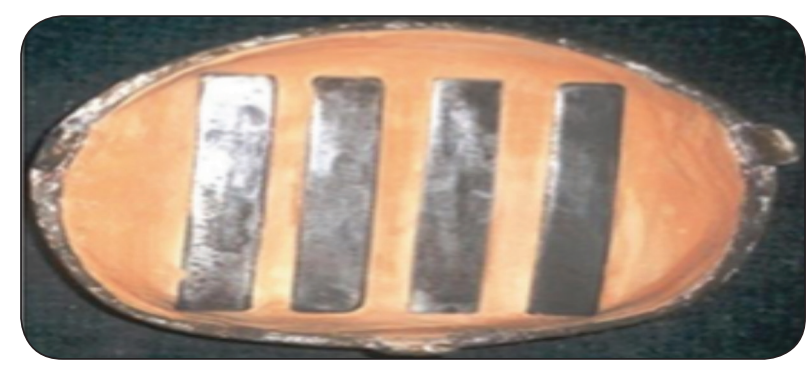

Fig. (1) Stainless-steel patterns invested in dental stone.

The finishing and polishing procedures of all specimens were done using a tungsten carbide bur for trimming, followed by ground with an emery paper120, 200, 400, and 600 grain respectively, to remove any remaining small scratches and to get a smooth, highly polished surface ${ }^{(28-30)}$ (Figure 2-4).

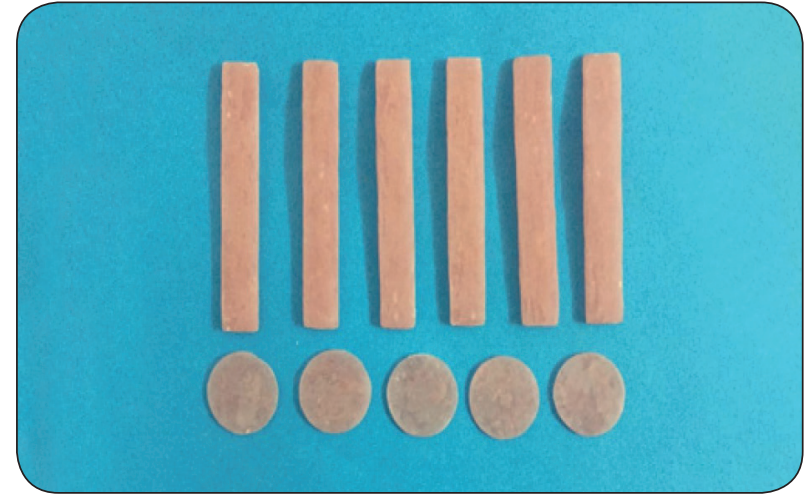

Fig. (2) Finished specimens of conventional PMMA acrylic resin.

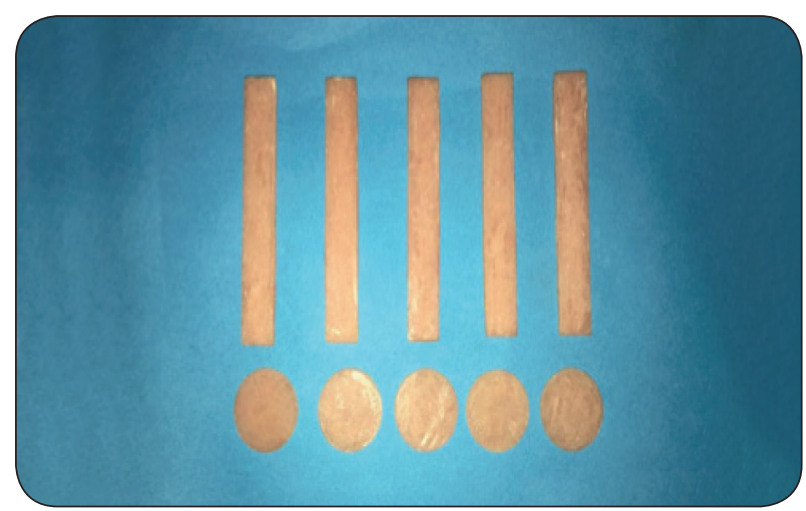

Fig. (3) Finished specimens of PMMA modified by $5 \%$ Henna.

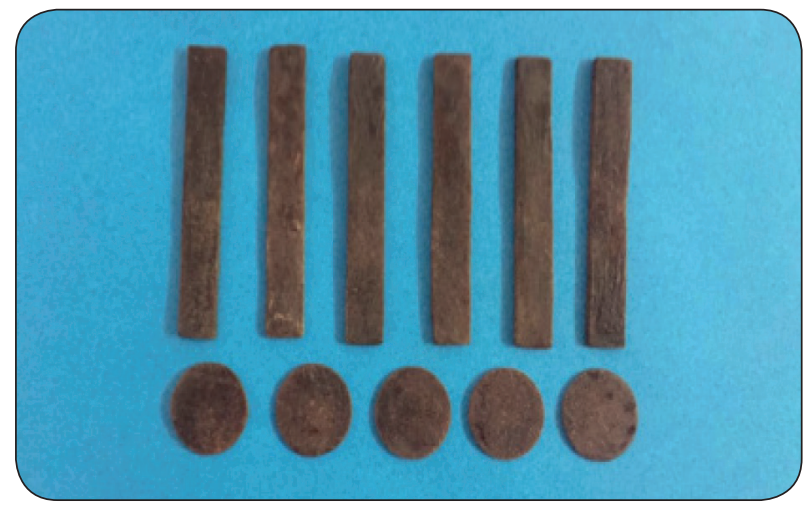

Fig. (4) Finished specimens of PMMA modified by Ag-Nps.

\section{Testing procedures:}

\section{1-Surface Hardness Test:}

Surface Micro-hardness of the specimens was determined using Digital Display Vickers MicroHardness Tester (Model HVS-50, Laizhou Huayin 
Testing Instrument Co., Ltd. China) with a Vickers diamond indenter and a 20X objective lens. A load of $200 \mathrm{~g}$ was applied to the surface of the specimens for 20 seconds. Three indentations, which were equally placed over a circle and not closer than 2 $\mathrm{mm}$ to the adjacent indentations, were made on the surface of each specimen. The diagonals length of the indentations was measured by a built-in scaled microscope and Vickers values were converted into micro-hardness values ${ }^{(31,32)}$. Micro-hardness was obtained using the following equation ${ }^{(32)}$.

Where HV: Vickers hardness in $\mathrm{kgf} / \mathrm{mm}^{2} ; \mathbf{F}$ : is the indentation load in kgf; and $\mathbf{d}$ is the arithmetic mean of the two diagonals in $(\mathrm{mm})$.

\section{2- Surface Roughness Test:}

Specimens were photographed using a USB Digital microscope with a built-in camera (Scope Capture Digital Microscope, Guangdong, China) connected with an IBM compatible personal computer using a fixed magnification of 90X (Figure 6). The images were recorded with a resolution of 1280 x 1024 pixels per image. Digital microscope images were cropped to 350 x 400 pixels using Microsoft office picture manager to specify and standardize area of roughness measurement. The cropped images were analyzed using WSx-M software.

Within the WSx-M software, all limits, sizes, frames and measured parameters are expressed in pixels. Therefore, system calibration was done to convert the pixels into absolute real-world units. Calibration was made by comparing an object of known size (a ruler in this study) with a scale generated by the software.

Subsequently, a 3D image of the surface profile of the specimens was created. Five 3D images were collected for each specimen, in the central area and in the sides at an area of $10 \mu \mathrm{m} \times 10 \mu \mathrm{m}^{(33,34)}$. WSx-M software was used to calculate the average of heights ( $\mathrm{Ra}$ ) expressed in $\mu \mathrm{m}$, which can be assumed as a reliable index of surface roughness.

\section{Statistical Analysis}

All collected data were analyzed with one-way ANOVA analysis of variance using SPSS V20 SPSS Chicago, IL, USA.

\section{RESULTS}

\section{1- Vickers Hardness:}

The statistical analysis results of the surface hardness of all tested groups exhibited that; there were statistically significant differences between all tested groups as indicated by One-way ANOVA test. It was found that the incorporation of Henna and Ag-Nps significantly decrease surface hardness of conventional heat-cured PMMA acrylic resin. Among the groups (fig.5); Tukey's pair-wise posthoc test showed a non-significant statistical difference ( $>0.05$ ) between modified groups. Therefore, both of Henna and Ag-Nps have the same adverse effect on hardness of heat-cured PMMA acrylic resin (Table 1).

Table (1) Comparison of Vicker's hardness test results among all tested groups.

\begin{tabular}{|c|c|c|c|}
\hline Variables & Mean & SD & $\boldsymbol{P}$-value \\
\hline Group 1 & $33.85^{\mathbf{A}}$ & 1.79 & \\
\hline Group 2 & $30.63^{\mathbf{B}}$ & 1.71 & \multirow{2}{*}{$0.031^{*}$} \\
\hline Group 3 & $31.49^{\mathbf{B}}$ & 2.16 & \\
\hline
\end{tabular}

*; significant $(p<0.05)$.

Different letters in the same column indicating a statistically significant difference $(p<0.05)$.

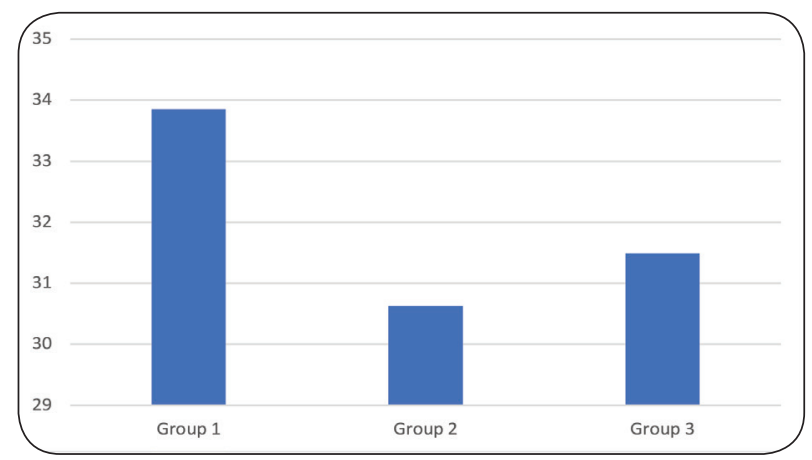

Fig. (5) Vicker's hardness test Mean values for all tested groups. 


\section{2- Surface Roughness:}

The statistical analysis results of surface roughness of all tested groups (Fig.6) revealed that; there were statistically non-significant differences between all tested groups as indicated by One-way ANOVA test. It was found that the incorporation of Henna and Ag-Nps showed a non-significant decrease in surface roughness when compared to conventional heat-cured PMMA acrylic resin (Table 2).

Table (2) Comparison of surface roughness test results between all tested groups.

\begin{tabular}{|c|c|c|c|}
\hline Variables & Mean & SD & $\boldsymbol{P}$-value \\
\hline Group 1 & 0.2592 & 0.003 & \multirow{2}{*}{1} \\
\cline { 1 - 3 } Group 2 & 0.2536 & 0.001 & \\
\hline Group 3 & 0.2563 & 0.002 & \\
\hline
\end{tabular}

*; significant $(p<0.05)$.

Different letters in the same column indicating a statistically significant difference $(p<0.05)$.

Followed by Tukey's test. Statistical analysis was done with (SPSS Chicago, IL, USA) with a significant level at $P$-value $<0.05$.

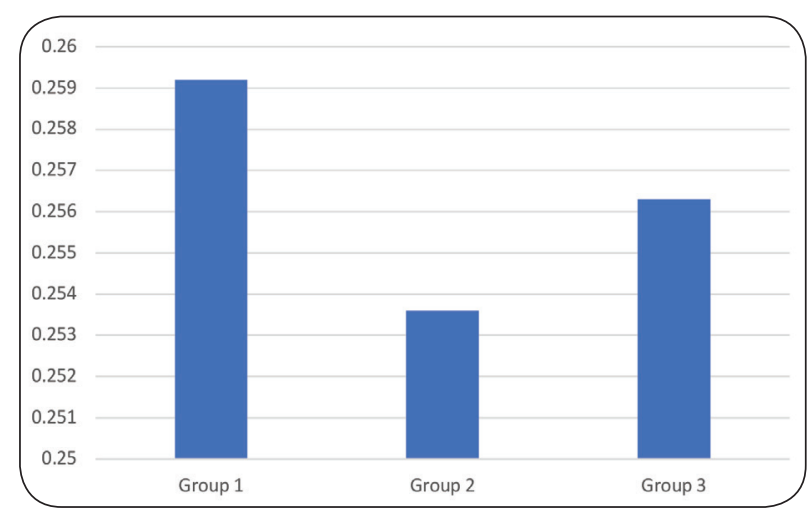

Fig. (6) Surface roughness test mean values for all tested groups.

\section{DISCUSSION}

PMMA resin has many advantages such as an excellent esthetic characteristic, low water sorption and solubility, adequate strength, low toxicity, easy repair, and a simple molding processing technique $^{(35-38)}$. However, it has some disadvantages such as polymerization shrinkage, relatively low flexural strength, lower impact strength, and low fatigue resistance ${ }^{(38)}$. The failure of PMMA denture base material is most likely in the form of fracture either due to flexural fatigue or impact forces ${ }^{(5,11,39,40)}$.

Several attempts have been made to improve the mechanical, physical and biological properties of the acrylic resin ${ }^{(41)}$. The aim of researches in these areas is to modifying the composition or reinforcing the PMMA with other stronger material for developing new material with better properties ${ }^{(11,41)}$.

Chemical modification and the addition of some rubber-like substances, fibers, fillers, and nanoparticles (NPs) are different methods introduced and commonly used in an attempt to improve the mechanical and physical properties of PMMA-based materials ${ }^{(11,41-43)}$.

Hardness is an important mechanical property most frequently used to characterize the wear resistance of the material that means; the material with higher surface hardness considered to be more wear-resistant ${ }^{(44)}$.

It is also, provides a possible indication of the abrasive resistance of the PMMA acrylic resin material which is the characteristic of the ease of finishing the material as it is resistant to in-service scratching during cleansing or handling ${ }^{(45-47)}$.

Improvement of acrylic resin hardness is one of the researcher's concerns. Since; a recent study showed that the surface of complete denture bases must be polished to provide comfort to patients, as well as adequate aesthetics, prosthesis hygiene and low level of biofilm retention ${ }^{(48)}$. 
The results of surface hardness of conventional heat-cured PMMA acrylic resin significantly decreased after the addition of Henna and Ag-Nps. This may be due to the interference of Henna and Ag-Nps with monomer conversion which leads to incomplete polymerization process of PMMA acrylic resin, resulting in a large amount of residual monomer ${ }^{(15,49-51)}$.

Additionally, it was found that there is no chemical reaction between "Ag-Nps / Henna" fillers and acrylic resin, hence, they can act as impurities within the resin matrix and subsequently weakening the materials and affecting their mechanical properties $^{(18,52,53)}$.

The surface roughness of denture base material is important as it affects the oral health of the tissues in direct contact with the denture ${ }^{(54,55)}$. Surface texture can significantly increase or decrease microbial adhesion, colonization, and biofilm maturation as well as it can cause tissue microtraumas ${ }^{(56,57)}$. According to Consani et al., ${ }^{(47)}$ the lower surface roughness, the lower stain catching of acrylic denture base material.

The results of the current study showed that Henna and Ag-Nps fillers, as an additive to the heatcured PMMA acrylic resin, insignificantly reduced the surface roughness ( $\mathrm{Ra}$ ) of the acrylic resin specimens. This, may be due to lake of their chemical reaction with PMMA acrylic resin which allow the filler to scattered on the matrix surface and thus closed the gaps within the resin matrix ${ }^{(58,59)}$. In addition, surface roughness concerned with the outermost layer of the specimen surface and measured only from the outer surface and not the inner surface of the acrylic resin specimen ${ }^{(60)}$.

\section{REFERENCES}

1. Alla RK, Sajjan S, Alluri V, Ginjupalli K, Upadhya N. Influence of fiber Reinforcement on the properties of Denture Base Resin. J Biomater Nano Biotech. 2013; 4(1):91-7.
2. Arora A, Chawla P, Gupta S, Gupta R. Metal Mesh Reinforced Denture as a Mean of Prevention Prosthodontics: A Case Report. J Upd Dent. 2011; 1(1): 1-4.

3. Vojdani M, Sattari M, Khajehoseini Sh, Farzin M. Cytotoxicity of Resin-Based Cleansers: An in Vitro study, Iranian Red Crescent Medical Journal. 2010; 12(2):15862.

4. El-Mahdy MH, El-Gheriani WE, Idris BA, Saad AHA. "Effect of coupling agents on the important physico- mechanical properties of acrylic resin rein- forced with ceramic filler," Ainshams Dent J. 2005; 8(2):243-54.

5. Alla RK, Raghavendra Swamy KN, Vyas R, Konakanchi A, Guduri V, Gadde P. Influence of Silver Nanoparticles Incorporation on Flexural Strength of Heat-cure Acrylic Denture Base Resin Materials. ARRB 2017;17(4): 1-8.

6. Meng TR Jr., Latta MA. Physical properties of four acrylic denture base resins. J Contemp Dent Pract. 2005;6(4):93-100.

7. Drabar UR, Huggett R, Harrison A. Denture Fracture - A Survey, Brit Dent J. 1994; 176(9):342-45.

8. Arikan A, Ozkan YK, Arda T, Akalın B. Effect of 180 days of water storage on the transverse strength of acetal resin denture base material, J Prosthodont. 2010; 19(1):47-51.

9. Nandal S, Ghalaut P, Shekhawat H, Gulati MS. New era in denture base resins: A review. D J AS. 2013; I(III):136-43.

10. Singh S, Palaskar JN, Mittal S. Comparative evaluation of surface porosities in conventional heat polymerized acrylic resin cured by water bath and microwave energy with microwavable acrylic resin cured by microwave energy. Contemp Clin Dent. 2013;4(2):147-51.

11. Jagger DC, Harrison A, Jandt KD. The reinforcement of dentures. J Oral Rehabil. 1999; 26:185-94.

12. Vallittu PK. Comparison of in Vitro Fatigue Resistance of acrylic resin partial denture reinforced with continuous glass fibers or metal wire. J Prosthodont. 1996;5(2):115- 121.

13. Unal H, Mimaroglu A. Influence of filler addition on the mechanical properties of nylon-6 polymer. J Reinf Plast Compos. 2004; 23:461-9.

14. Makavandi P, Nikfarjam, Sanjani NS, Qazvini NT, Effect of silver nanoparticle on the properties of polymethyl methacrylate) nanocomposite network made by in situ photooniferter-mediated photopolymerization. Bull mater Sci. 2015;38(6):1625-31.

15. Zhang Y, Chen Y-Y, Huang L, Chai Z-G, Shen L-J, Xiao $\mathrm{Y}-\mathrm{H}$. The antifungal effects and mechanical properties of silver bromide/cationic polymer nanocomposite-modified 
polymethyl methacrylate-based dental resin. Scientific Reports. 2017; 7(1):1-12.

16. Salih SI, Oleiwi JK, Mohamed AS. Investigation of Mechanical Properties of PMMA Composite Reinforced with Different Types of Natural Powders. ARPN J Eng Appl Sci. 2018; 13(22): 8889-900.

17. Hamid SK, Al-Dubayan AH, Al-Awami H, Khan SQ, Gad MM. In vitro assessment of the antifungal effects of neem powder added to polymethyl methacrylate denture base material. J Clin Exp Dent. 2019;11(2): e170-8.

18. Nawasrah A, Gad MM, El Zayat M. Effect of Henna Addition on the Surface Roughness and Hardness of Polymethylmethacrylate Denture Base Material: An in vitro Study. J Contemp Dent Pract 2018;19(6):732-38.

19. Gad MM, Rahoma A, Nawasrah A, Ammar MM. Influence of Henna Addition on The Flexural Strength of Acrylic Denture Base Material: An In Vitro Study. ADJ-for Girls 2018; 5(3): 277-83.

20. Sujanmulk B, Chintamaneni R, Chennupati A, Nahar P, Chaluvadi R, Vemugunta R, et al. Evaluation of antifungal efficacy of ethanolic crude lawsone and listerine mouthwash in uncontrolled diabetics and denture wearers - A Novel Clinical Trial. J Clinic Diagn Rese. 2016;10(6): 90-9.

21. Ghahremanloo A, Movahedzadeh M. The effect of silver nano particles on Candida albicans and Streptococcus mutans in Denture Acrylic Resins. J Dent Mater Tech 2016; 5(1):23-30.

22. Kassaee MZ, Akhavan A, Sheikh N, Sodagar A. Antibacterial effects of a new dental acrylic resin containing silver nanoparticles. J Appl Polym Sci. 2008;110: 1699-703.

23. She WJ. Basic study of denture base resin with nano-silver antibacterial agent. Dent Mater J. 2004; 27: 176-80.

24. Nawasrah A, AlNimr A, Ali AA. Antifungal Effect of Henna against Candida albicans Adhered to Acrylic Resin as a Possible Method for Prevention of Denture Stomatitis. Int. J. Environ. Res. Public Health 2016, 13, 520: 2-8.

25. Koroglu A, Sahin O, Kurkcuoglu I, Dede D, Ozdemir T, Hazer B. Silver nanoparticle incorporation effect on mechanical and thermal properties of denture base acrylic resins. J Appl Oral Sci. 2016. 24(6): 590-96.

.62 Mekkawy M, Hussein L, Alsharawy M. Comparative study of surface roughness between polyamide, thermoplastic polymethyl methacrylate and acetal resins flexible denture base materials before and after polishing. Life Sci J. 2015;12(10):577-81.

27. Jang D, Lee J, Hyun S, Jang H, Son M. "Color stability, water sorption and cytotoxicity of thermoplastic acrylic resin for non-metal clasp denture. $\mathrm{J}$ adv prosthod. 2015;7(4): 278-87.

28. British Standards. Dentistry-Base polymers BS EN ISO 20795-1:2008; British Standards Institution (BSI): London, UK, 2008; p. 36.

29. British Standards. British Standard Specification for Denture base Polymers BS 2487:1989 ISO 1567:1988; British Standards Institution (BSI): London, UK, 1989; p. 10.

30. Gharechahi J, Asadzadeh N, Shahabian F, Gharechahi M. Flexural Strength of Acrylic Resin Denture Bases Processed by Two Different Methods. J Dent Res Dent Clin Dent Prospects. 2014; 8(3): 148-52.

31. Yesil Duymus Z, Ozdogan A, Ulu H, Ozbayram O. Evaluation the Vickers Hardness of Denture Base Materials. Open J Stoma. 2016; 6: 114-9.

32. ASTM E384-10. Standard test method for Knoop and Vickers hardness of materials. ASTM International, PA, USA, 2010.

33. Pisani MX, Lovato da Silva CH, Paranhos HF, Souza RF, Macedo AP. The Effect of Experimental Denture Cleanser Solution Ricinus communes on Acrylic Resin properties. Mat. Res. 2010; 13(3): 369-73.

34. Kakaboura A, Fragouli M, Rahiotis C. Evaluation of surface characteristics of dental composites using pro lometry, scanning electron, atomic force microscopy and glossmeter. J Mater Sci Mater Med. 2007; 18:155-63.

35. Figuerôa RM, Conterno B, Arrais CA, Sugio CC, Urban VM, Neppelenbroek KH, et al. Porosity, water sorption and solubility of denture base acrylic resins polymerized conventionally or in microwave. J Appl Oral Sci 2018;26: e20170383.

36. Zirak M, Vojdani M, Mohammadi S, Khaledi AA. Comparison of the water sorption and solubility of four reline acrylic resins after immersion in food-simulating agents. J Int Soc Prevent Communit Dent 2019; 9:40-6.

37. Anusavice J. Philips. Science of Dental Materials, 11th ed. New Delhi, India: Elsevier Puplishers;2016. p.721- 58.

38. Vojdani M, Giti R. Polyamide as a Denture Base Material: A Literature Review. J Dent (Shiraz). 2015; 16(1):1-9.

39. Wiskott HW, Nicholls JI, Belser UC. Stress fatigue: basic principles and prosthodontic implications. Int $\mathrm{J}$ Prosthodont. 1995; 8:105-16. 
40. Sivasaranya B, Lambodharan R, Vigneshwar V, Sankarakrishnan S. Midline fracture in single complete denture and its various treatment modalities. Interna $\mathrm{J}$ Scient Rese.2017;6(11):226-7.

41. Alla RK, Raghavendra N, Vyas R, Konakanchi A. Conventional and Contemporary polymers for the fabrication of denture prosthesis: part I - Overview, composition, and properties. Inter J Appli Dent Scien. 2015; 1(4): 82-9.

42. Mahross HZ, Baroudi K. Effect of silver nanoparticles incorporation on viscoelastic properties of acrylic resin denture base material. Eur J Dent 2015; 9(2):207-12.

43. Ongun S, Kurtulmus S, Meriç G, Ulusoy M. A Comparative Study on the Mechanical Properties of a Polymer-Infiltrated Ceramic-Network Material Used for the Fabrication of Hybrid Abutment. Materials (Basel). 2018;11(9):1681-95.

44. Sakaguchi RL, Powers JM. Craig's Restorative Dental Materials. 13th ed. USA: Elsevier Inc.; 2012.p.191-99.

45. De Rezende Pinto L, Rodriguez Acosta EJT, Távora, FFF, Da Silva PMB, Porto VC. Effect of repeated cycles of chemical disinfection on the roughness and hardness of hard reline acrylic resins. Gerodontology. 2010; 27, 147153.

46. Bahrani $\mathrm{F}$ and Khaledi A. Effect of surface treatments on shear bond strength of denture teeth to denture base resins. Dent Res J (Isfahan). 2014;11(1): 114-18.

47. Consani RLX, Folli BL, Nogueira MC, Correr AB, Mesquita MF. Effect of Polymerization Cycles on Gloss, Roughness, Hardness and Impact Strength of Acrylic Resins. Braz Dental J. 2016; 27: 176-80.

48. Alammari M. The influence of polishing techniques on pre-polymerized CAD $\backslash C A M$ acrylic resin denture bases. Electron Physician. 2017; 9(10):5452-8.

49. Davies IJ, Rawlings RD. Mechanical properties in compression of CVIdensiled porous carbon/carbon composite. Compos Sci Technol. 1999; 59:97-104.

50. Arora P, Singh SP, Arora V. Effect of alumina addition on properties of poly-methyl methacrylate-a comprehensive review. Int J Biotech Trends Technol 2015; 5:1-7.
51. Shibata T, Hamada N, Kimoto K, Sawada T, Sawada T, Kumada H, Umemoto T, Toyoda M. Antifungal Effect of Acrylic Resin Containing Apatite-Coated TiO2 Photocatalyst. Dent Mater J. 2007; 26:437-44.

52. Ghaffari T, Hamedi-Rad F. Effect of Silver Nano- particles on Tensile Strength of Acrylic Resins. J Dent Res Dent Clin Dent Prospects. 2015; 9:40-3.

53. Turki MM, Abdul-Ameer FM. Influence of Silver Nanoparticles on the Specific Properties of Acrylic Resin for Ocular Prosthesis. Biomed Pharmacol. J, 2018; 11(3), 1573-81.

54. Kolenbrander PE, Andersen RN, Blehert DS, Egland PG, Foster JS, Palmer RJ. 2002. Communication among oral bacteria. Microbiology and molecular biology reviews, 66, 486-505.

55. Mahross H, Mohamed M, Hassan A, Baroudi K. Effect of Cigarette Smoke on Surface Roughness of Different Denture Base Materials J Clin Diagn Res. 2015 Sep;9(9):39-42.

56. Cunha TR., Regis RR, Bonatti MR, Souza RFD. Influence of incorporation of fluoroalkyl methacrylates on roughness and flexural strength of a denture base acrylic resin. J Appl Oral Sci. 2009; 17: 103-7.

57. Zamperini CA, Machado AL, Vergani CE, Pavarina AC, Giampaolo E T, Da Cruz NC. Adherence in vitro of Candida albicans to plasma treated acrylic resin. Effect of plasma parameters, surface roughness and salivary pellicle. Arch Oral Biolo. 2010; 55: 763-70.

58. Azeez ZA, Fatah NA. The effect of incorporation of prepared Ag-Zn Zeolite on some properties of heat polymerized acrylic denture base materials. J Bagh Coll Dent. $2015 ; 27: 63-9$.

59. Aydogan Ayaz E, Durkan R, Bagis B. The effect of acrylamide incorporation on the thermal and physical properties of denture resins. The journal of advanced prosthodontics. 2013; 5, 110-17.

60. Ihab N. Evaluation the effect of modified nano-fillers addition on some properties of heat cured acrylic denture base material. JBCD. 2011; 23(3):23- 27. 


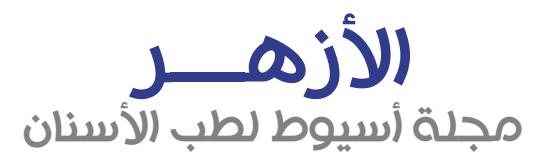

النشر الرسمي لكلية طب الأسنان

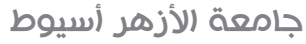

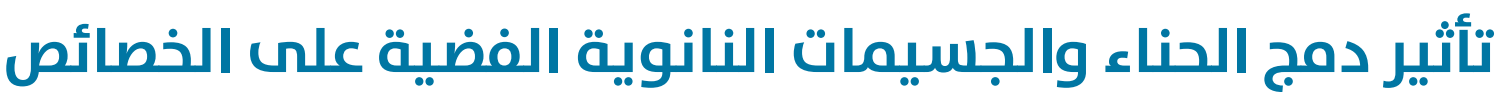

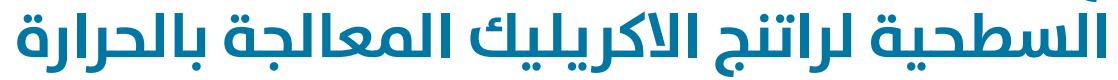

جمال مختار الوايِّ (1) ، مصطفى إبراهيه فياض (1,2), رامي عبد الله عبد الرحيم (3) ، أسامة أبو هلال (1)

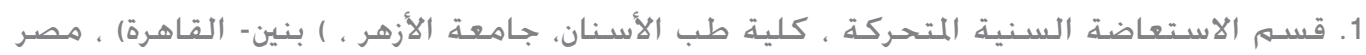

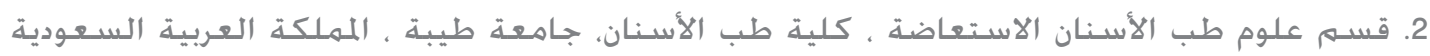

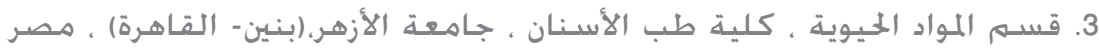

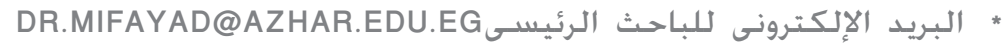

الملخص :

الهدف: هدفت هذه الدراسة إلى تقييم تأثير حشو الحناء والجسيمات النانوية الفضية على الخصائص السطحية لراتنج أكريليك البولي ميثيل ميثاكريلات

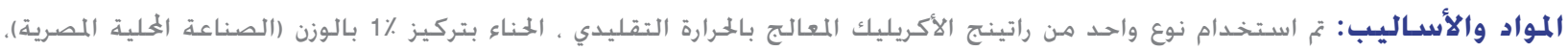

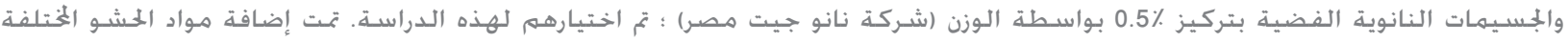

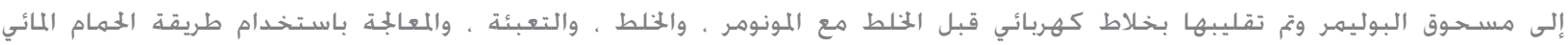

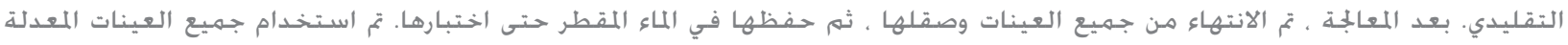
وغير المعدلة لقياس صلابة السطح وخشونة السطح. تم إجراء ختلبل البيانات الإحصائية عبر برناهج

النتائج: إن دمهج الحناء و والجسبمات النانوية الفضية يقلل بشكل كبير من صلابة سطح راتنجات أكريليك البولي ميثيل ميثاكريلات في بي

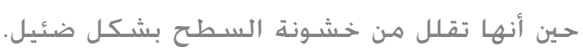

الخلاصة : الصلابة السطحية لراتنجات أكريليك البولي ميثيل ميثاكريلات تتأثر سلبًا بتضمين المشوات ، بينما تتحسن خشونة السطح. الكلمات المفتاحية: لراتنجات أكريليك البولي ميثيل ميثاكريلات ، المناء، الجسبمات النانوية الفضية, خواص السطح، الصلابة السطحية. 